\title{
Using Ellenberg-Pignatti values to estimate habitat preferences of wild food and medicinal plants: an example from northeastern Istria (Croatia)
}

\author{
Ivana Vitasović Kosić ${ }^{1}$, Josip Juračak² and Łukasz Łuczaj ${ }^{3^{*}}$ (D)
}

\begin{abstract}
Background: The paper presents the first ethnobotanical application of Ellenberg indicator values, which are widely used in European plant ecology. The aim of the study was to find out if Ellenberg values (indicating habitat preferences) differ for wild food and medicinal plants used in north-eastern Istria (Croatia). We used Ellenberg-Pignatti values (the version of Ellenberg values used in this part of Europe).

Methods: Fifty semi-structured interviews were carried out among local key informants, asking which wild food and medicinal plants they used.

Results: The mean number of food and medicinal plants mentioned per interview was 30. Altogether, 121 species were recorded as food or medicine used or previously used in the study area. Thirty-one species are used exclusively as food or everyday drink, 50 species are used exclusively as medicine and 40 species are used for both food and medicine. There were no significant differences between Ellenberg values for food and medicinal plants, apart from the Nitrogen indicator value - the plants used exclusively as food had a significantly higher index than those used in medicine. This probably stems from the fact that plants with soft fleshy shoots are attractive as food and they are more likely to come from nitrogen-rich ruderal habitats.

Conclusions: Food plants and medicinal plants are collected from a variety of habitats and no clear difference between the two categories of plants was detected, however further testing of Ellenberg values in ethnobotanical studies could be interesting.
\end{abstract}

Keywords: Ethnoecology, Quantitative ethnobotany, Ellenberg indicator values, Wild edible plants, Medicinal plants, Cićarija, Phytoindication, Ethnobotany, Ethnomedicine

\section{Background}

Ellenberg values are indices given to each species in a flora to express the species' environmental preferences $[1,2]$. The system was first introduced by the prominent German phytosociologist Heinz Ellenberg (1913-1997), and applied to the vegetation of central Europe. It consists of the following indices: Light, Temperature, Continentality, Soil Moisture, Reaction, Nitrogen and Salinity. Later it was modified to incorporate local

\footnotetext{
* Correspondence: lukasz.luczaj@interia.pl

${ }^{3}$ Department of Botany, Institute of Biotechnology, University of Rzeszów, Werynia 502, 36-100 Kolbuszowa, Poland

Full list of author information is available at the end of the article
}

differences in species' environmental preferences, e.g. in Switzerland, Poland, British Isles and Italy [3-6]. EllenbergPignatti values from Italy are used in the Mediterranean part of Croatia, as the climate and vegetation zones of Croatia bear many similarities to those of the adjacent Italy.

The values are usually given on a ten grade scale (0-9), apart from Light, Temperature and Soil Moisture, expressed on a $0-12$ scale and salinity on a $0-3$ scale. They are based on the field experiences of ecologists. Although looking at single species values does not have much practical use, comparison of average values for different sites and habitats can be used for phytoindication and characterizing environmental conditions at a given 
site $[7,8]$. Some reductionist-oriented ecologists criticise the values for being based on biased choices and impressions and for mixing the absolute requirements of species with their ecological niches, which are the results of competition $[9,10]$. Being aware of the constraints in using these values in our article, we aimed at applying them to ethnobotanical data.

The data matrix in an ethnobotanical study has many similarities with a phytosociological study. In the latter we obtain a data sheet composed of a species $\mathrm{x}$ releve matrix, whereas in the former we usually have a similar species $\mathrm{x}$ informant matrix which is later analysed. In both cases the same indices and tools may be used to describe the data: species frequency, diversity indices, ordination methods etc. Increasing quantification of ethnobotanical studies has been continuously advocated by some ethnobotanists, particularly by Ulysses de Albuquerque and his colleagues $[11,12]$. This would strengthen the discipline and provide rigorous testing methods. Species frequency and diversity indices are probably used in at least half of ethnobotanical papers. However, other numerical methods and tools used in ecology, such as ordination techniques (see e.g. [13] from the similar study area), are used less frequently.

Traditional knowledge usually extends to different habitats surrounding human settlements. However, it has been noticed that it is not evenly distributed. For example ruderal "weedy" species tend to be over-utilized compared to the species of primary forest habitats $[14,15]$, although the opposite can be true in some cultures as well [16]. Writing this paper we wanted to explore the use of Ellenberg values to establish whether there are differences between the environmental preferences of wild medicinal and food plants. We assumed that some Ellenberg values would be different for food and medicinal plants, as medicinal plants are often rich in essential oils and alkaloids, so they would tend to grow in dry pastures and grasslands, while food plants should be gathered from more nutrient-rich and mesic habitats. An additional aim was to document the use of plants from the whole foodmedicine spectrum in the area.

For our case study we used the area of Cićarija in the north-eastern part of the Istria peninsula. Only two ethnobotanical studies dealing with plant remedies had previously been carried out there, covering several villages in the core part of Cićarija $[13,17]$. One of these studies concerned Croatians [13], another - Istro-Romanians [17]. In this paper we extended the research topic to food plants and included more villages from the area at the base of Ćićarija. The study was made easier by the fact that the first authors had carried out long term phytosociological research in the same area between 2003 and 2015 [18-21] and acquired a good level of knowledge about the local community and available key informants over the years. Our study was restricted to inhabitants of Croatian nationality.

\section{Study area}

The study area (about 1000 ha) is part of the North Adriatic Karst and is located in Croatia at the north of the Istrian Peninsula, on the Cićarija (Ital. Cicceria,

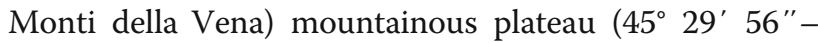
$45^{\circ} 30^{\prime} 00^{\prime \prime} \mathrm{N}, 13^{\circ} 59^{\prime} 54^{\prime \prime}-14^{\circ} 00^{\prime} 29^{\prime \prime} \mathrm{E}$ ), ranging 250 $900 \mathrm{~m}$ a.s.l (Figs. 1 and 2). The name Ćićarija is derived from the South Slavic term Ćić, which refers to Istrians living north and north-east of the Učka mountain, originally referring to the Vlachs and Istro-Romanians of the area [22]. The area belongs to the Special Protection Area (SPA) of the Natura 2000 network (92/43/EEC Directive) as an important site for habitat 62A0 (Eastern sub-mediterranean dry grasslands Scorzoneratalia villosae $\mathrm{H}$-ić 1975) and bird species conservation. The climate is transitional between Mediterranean and continental pre-Alpine, with cool, rainy winters and long, dry summers [23]. The mean annual temperature is $12.6{ }^{\circ} \mathrm{C}$, the coldest in February $\left(0-2{ }^{\circ} \mathrm{C}\right)$ and warmest in July or August $\left(18-22{ }^{\circ} \mathrm{C}\right)$. Precipitation is about $1500 \mathrm{~mm} /$ year, most of which falls in autumn; a less pronounced secondary peak occurs as spring turns to summer. From a bioclimatic viewpoint, the study area belongs to the sub-Mediterranean belt [24] and the epiMediterranean mountain zone. The territory is characterised by karstic phenomena (dolines, caves, etc.); the bedrock consists of limestone; soils are generally brown, shallow and clast-rich. Pastures are for the most part under-grazed because of a low density of grazers (sheep) or abandoned (Fig. 3); meadows are irregularly mown, abandoned or, in some cases, derive from seeded forage meadows that have been abandoned [18]. In the past (pre-World War II) most of the Ćićarija territory was karst and grassland. The pastoral landscape is characterized by pastures and meadows, belonging to the Scorzoneretalia villosae order (Festuco-Brometea class) and Arrhenatheretalia elatioris order (Molinio-Arrhenatheretea class; Fig. 4), respectively [18-21].The potential natural vegetation of most of the area is composed of subMediterranean forests of Quercetalia pubescentis Br.-Bl. (1931) 1932 order and, at higher elevations, Fagetalia sylvaticea Pawl. 1928 [21]. A complex mosaic of ruderal vegetation occurs in the villages (Fig.5).

For many centuries Istria was at the cross-roads of cultural exchange and trade between the Austrian Empire and the Republic of Venice. Cićarija, especially, was an area of frequent migrations due to wars and other disastrous events like plague epidemics. Therefore, even today it is considered as an area of multicultural interactions between peoples that have settled here throughout history (Croatians, Istro-Romanians, Slovenians, Italians and Austrians), and many people are multilingual. These historical events have influenced the creation of traditions and the mentality of people on this mountain. 


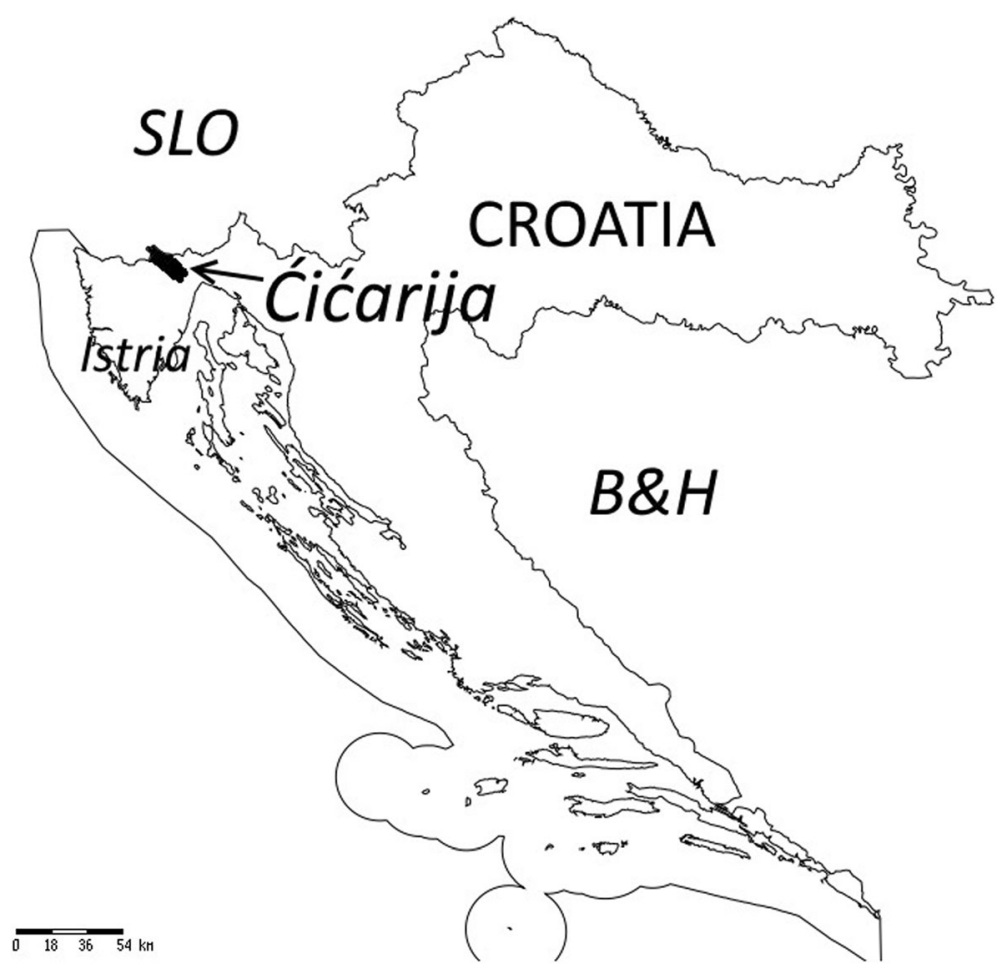

Fig. 1 Location of Cićarija in Croatia

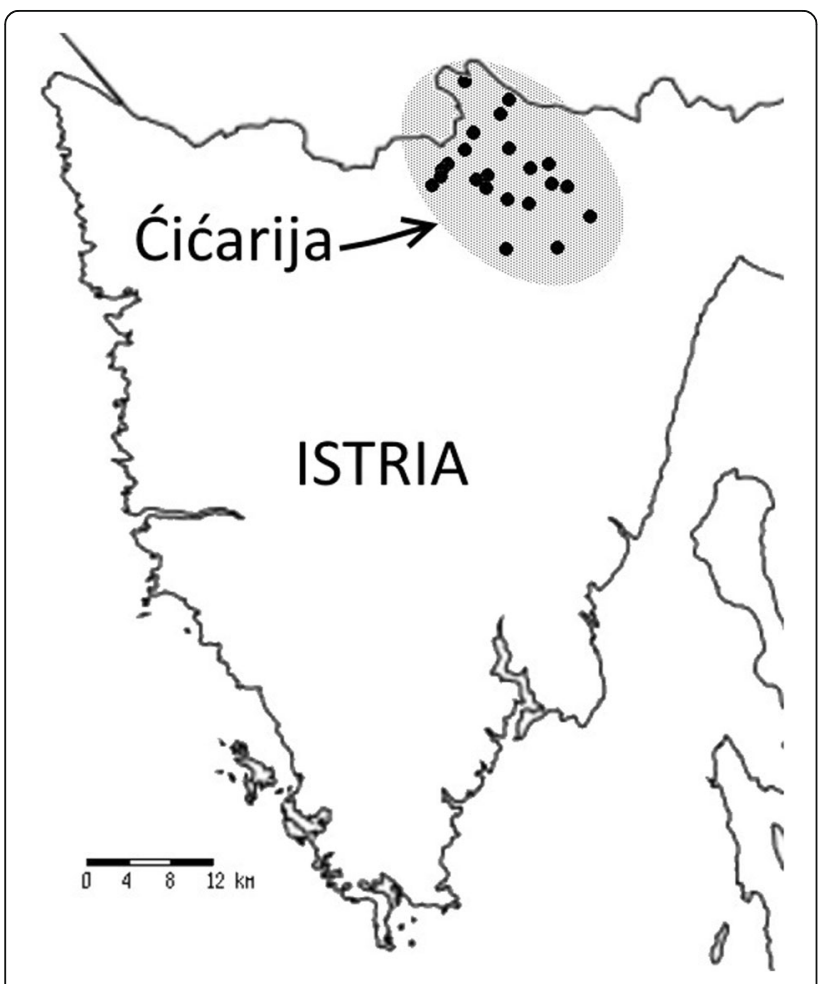

Fig. 2 Location of the Ćićarija villages in the study area
In this region sheep grazing and the herding way of life has been present for centuries. At the time of agrarian overpopulation (the 19th and the beginning of the twentieth century) large areas of the karst area in Cićarija were turned into barren, rocky grasslands, almost desert regions which were later afforested (mostly with Pinus nigra). After World War II, traditional ways of farming have been abandoned and there is a movement towards the farmyard way of livestock breeding [26], as well as the termination of transhumance from the southern parts of Istria, or even from distant regions (Bosnia and Herzegovina and

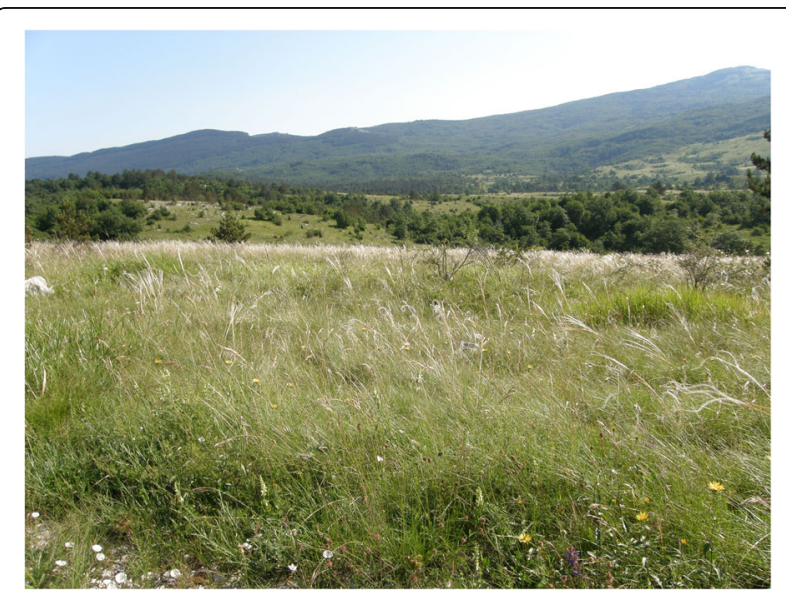

Fig. 3 The landscape of abandoned pastures in the study area 


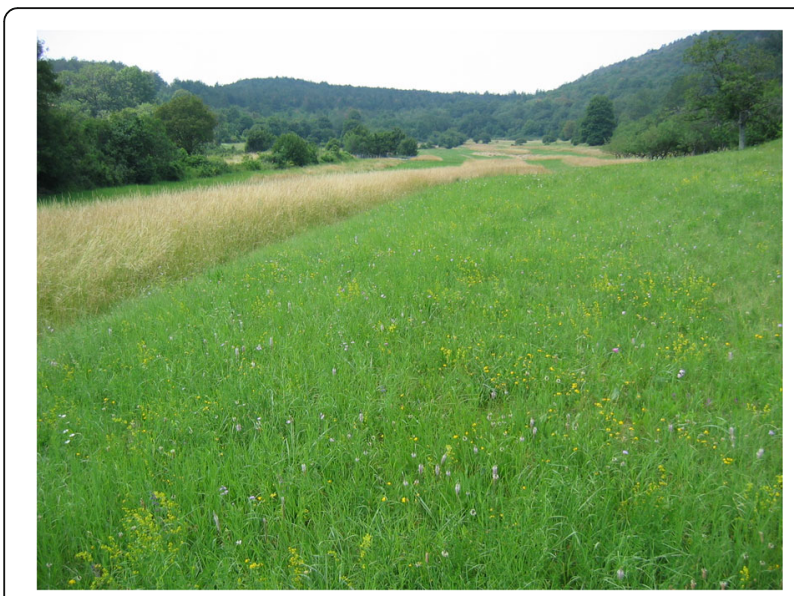

Fig. 4 Hay meadows and forests in the study area

Macedonia). Back in 1869 there were 160,000 sheep in Istria, whereas in 2003 there were only 12, 000 [25]. Nowadays in the area described there are about 200 sheep (I.J., information from local farmers).

Therefore, today in the area of Cićarija negative trends such as the abandonment of land, secondary succession, large-scale fires, reducing the number of population in distant areas, the disappearance of plant and animal species (loss of biodiversity) are present [26]. With the entry into force of the European "green" agricultural policy, agri-environmental measures have been taken to prevent further succession, to preserve the cultural landscape and biodiversity and to increase population density. Today the area of Ćićarija is populated by a predominantly elderly population, the younger people are employed in nearby towns, do not continue sheep husbandry, but either switch into agritourism or come to the mountains for the weekend or during the holidays.

Karst cultural landscape is characterized by fences with stone walls and fenced hay meadows. Some land is still

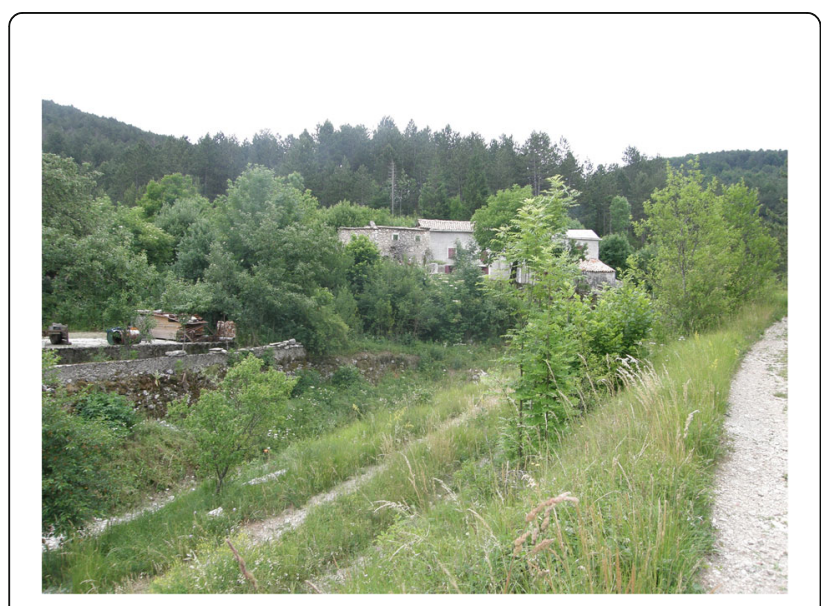

Fig. $5 \mathrm{~A}$ view of a settlement in the study area jointly owned by members of the agricultural community, the so-called "komunele" or "gmajne" (from German die Gemainde, in the translation community) [26].

Utilised arable land and meadows in the wider area (19,890 ha) occupy 1908 ha (75.8\% of utilised agricultural land, and $8.6 \%$ of the total surface), and predominantly karst pastures of low quality cover 608 ha $(24.2 \%$ of utilised agricultural land) [27, 28].

Most of the pasture land is undergoing further succession to woodlands, which occupy 13,611 ha $(68.4 \%$ of the total surface) [28]. These are the data for the areas of Buzet, Lanišće and Lupoglav, which are the only available data. In the narrower area of Ćićarija the share of agricultural land, especially arable land, is expected to be significantly smaller. Local people even today use a mixture of three languages, Croatian, Slovenian and Italian, easily switching between them. Additionally there is a community of Istro-Romanians who have their own language and traditions (village of Žejane), they probably arrived in Istria in around the fourteenth century from the Carpathians.

The population of the Croatian villages of the Cićarija speak both the Cakavian dialect of Croatian, which is also spoken in many other areas of Istria and along the Croatian Adriatic sea coast (Dalmatian littoral and islands) [13] and the Kajkavian dialect (near the border with Slovenia).

The northeastern border of Cićarija follows the road Rijeka - Trieste, while the southwestern border follows the route Lupoglav - Buzet. There are 22 villages in the Croatian part, mostly in the municipality of Lanišće, with 1722 inhabitants registered during the Census of 2011 [27]. In a broader sense, the parts of Buzet and Lupoglav municipalities also belong to Cićarija, and in that sense the total population in the area is about 5500. Today the higher mountain areas are almost abandoned, with less than 300 people remaining as permanent residents. Most of the population lives in the south eastern part of Cićarija, in the proximity of Rijeka. However, in the higher, central part of Cićarija there are 14 small villages with an average population of 24 people each. Only five of these villages have more than 20 inhabitants.

The population of Cićarija is in decline, and the current population is about a third of that from 1931 (from 8445 to 1722 inhabitants). The depopulation process was the most severe in the municipality of Lanišce, where the population density is 2.7 inhabitants per square $\mathrm{km}$ and the proportion of older people (age $>60$ ) is over $40 \%[27,28]$. The average age in the Lanišće municipality in 2011 was 49, which is 6.7 years more than in the Istria County as whole.

During the first half of the twentieth century the majority of active population on Ćićarija were working in agriculture, forestry and charcoal production. In every larger settlement there were craftsmen to provide necessary services: tailors, carpenters, blacksmiths, barbers, masons etc. 


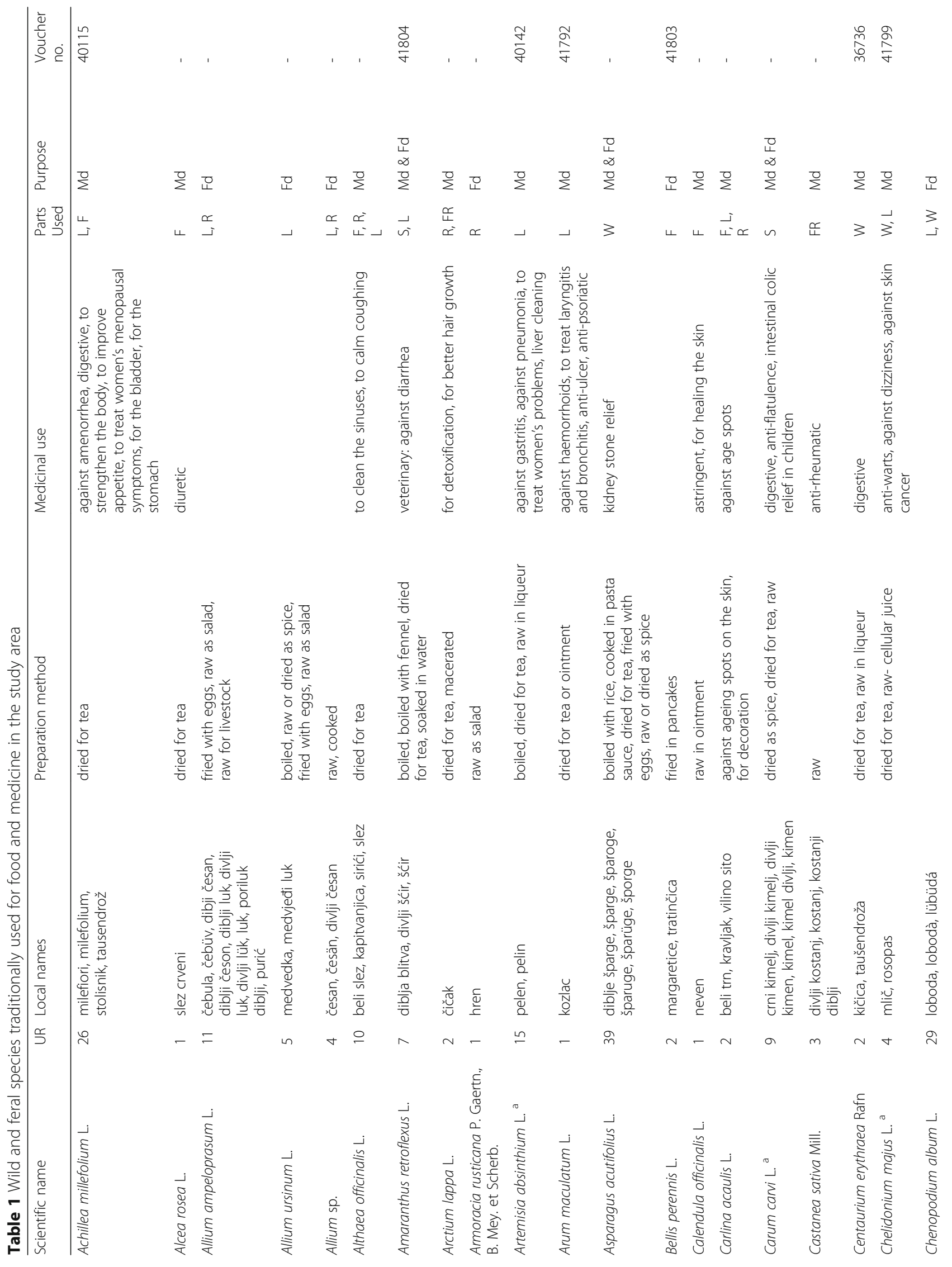




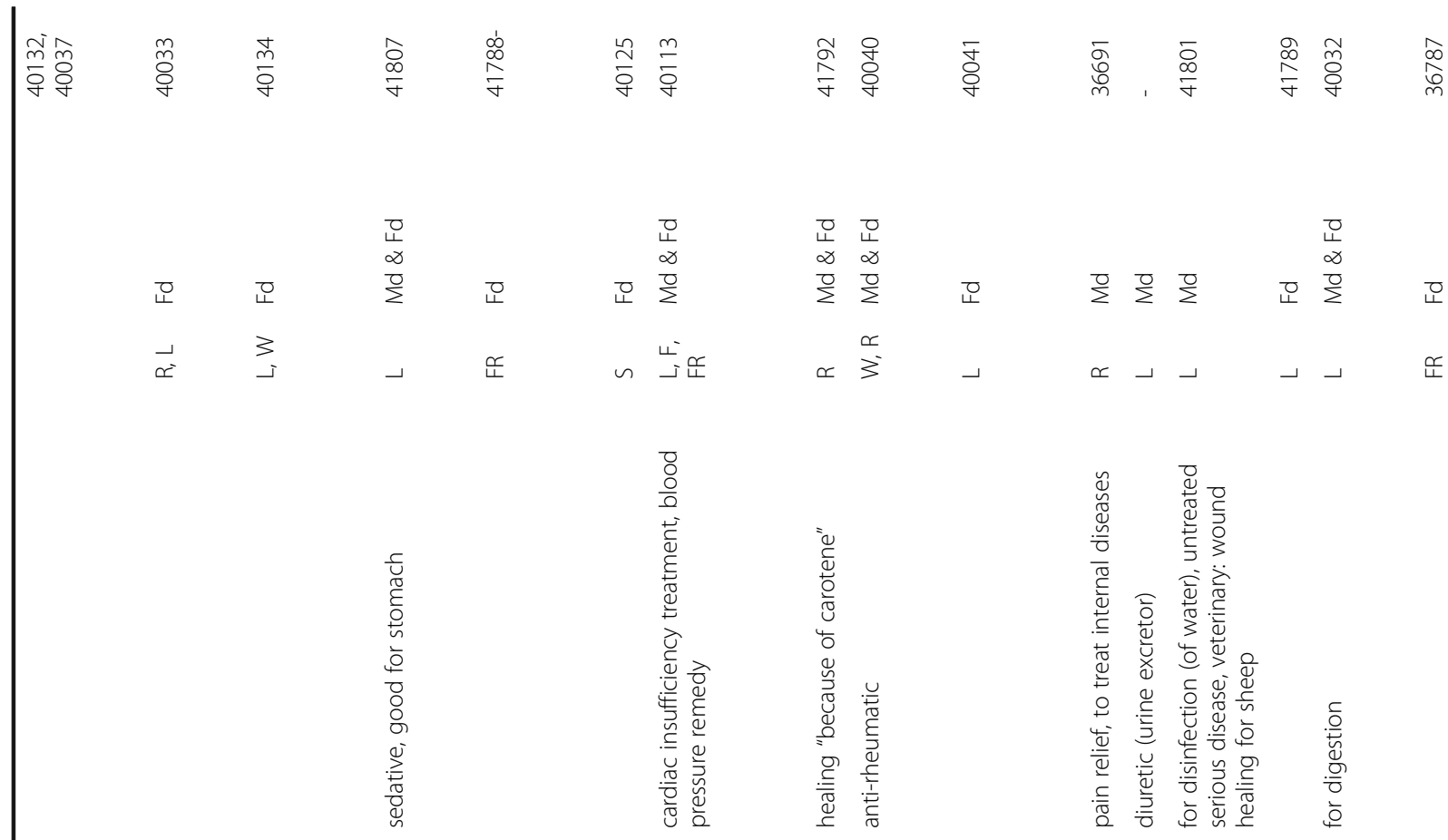

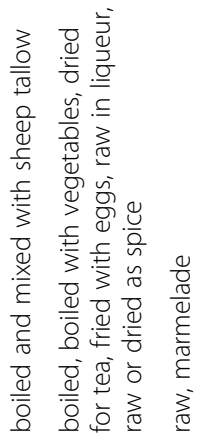

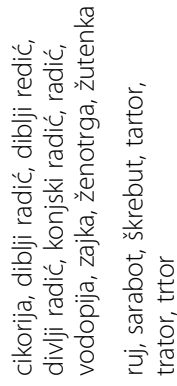

मे

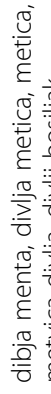

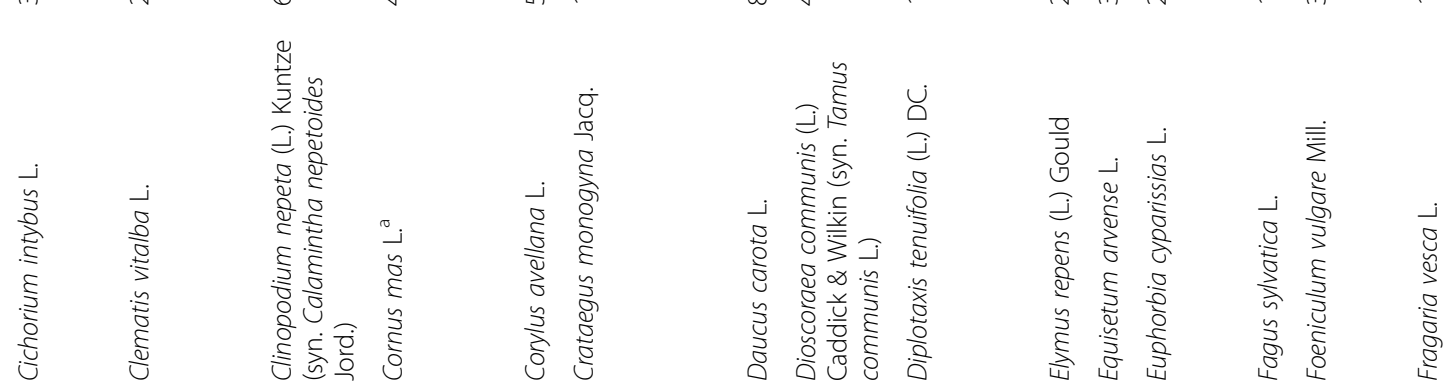

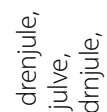

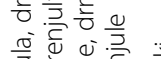

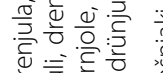

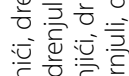

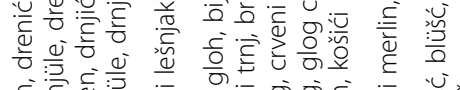

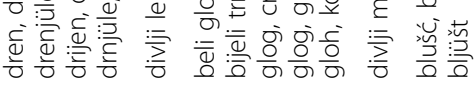

\&) 计

$\infty$ ㅇ

ㅇ

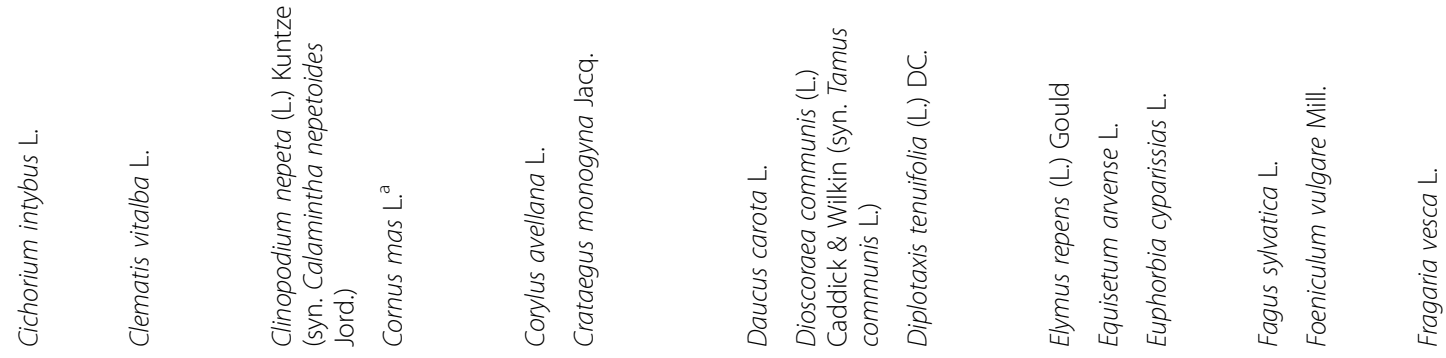

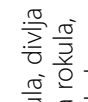

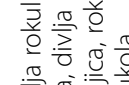

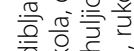

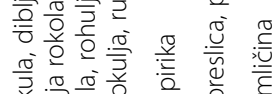

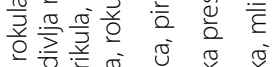

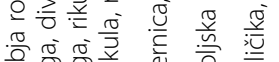

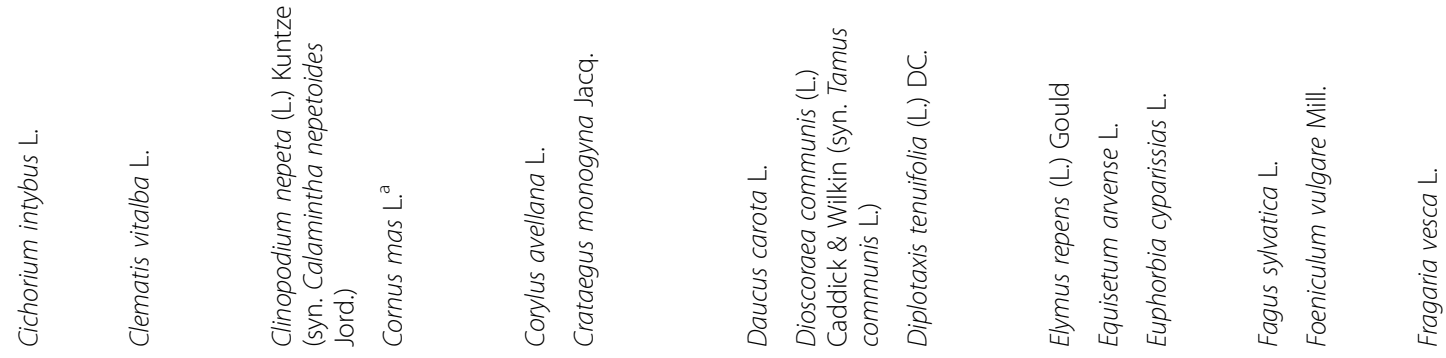

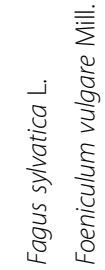

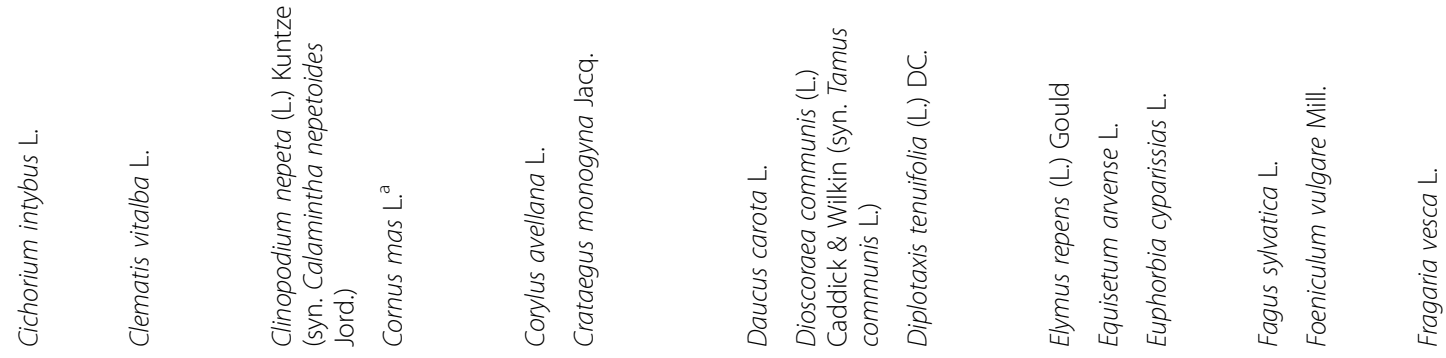

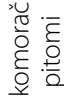
勿

产 辛<smiles>C1[AsH][AsH]1</smiles><smiles>[TeH]</smiles>

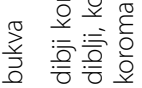

- $\bar{m} \quad \underline{\varphi}$ 


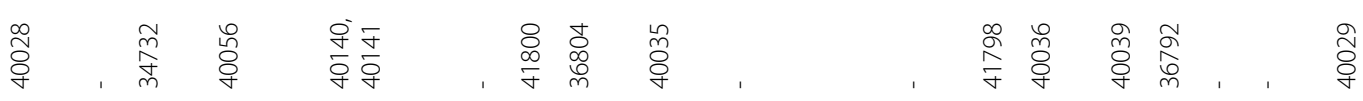

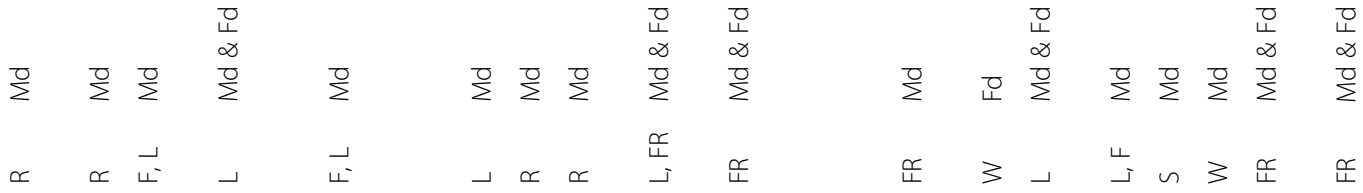
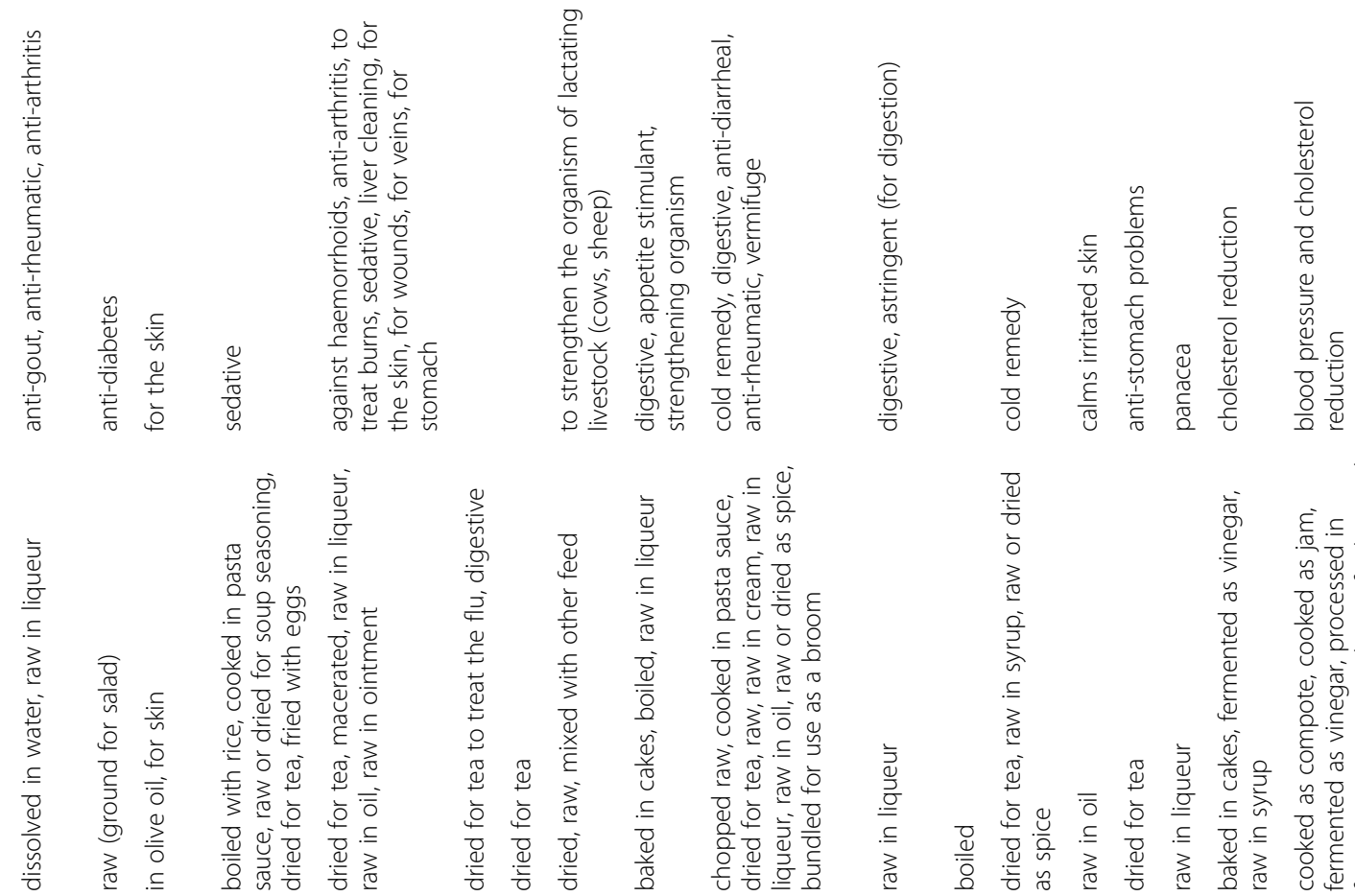

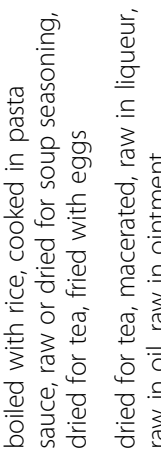
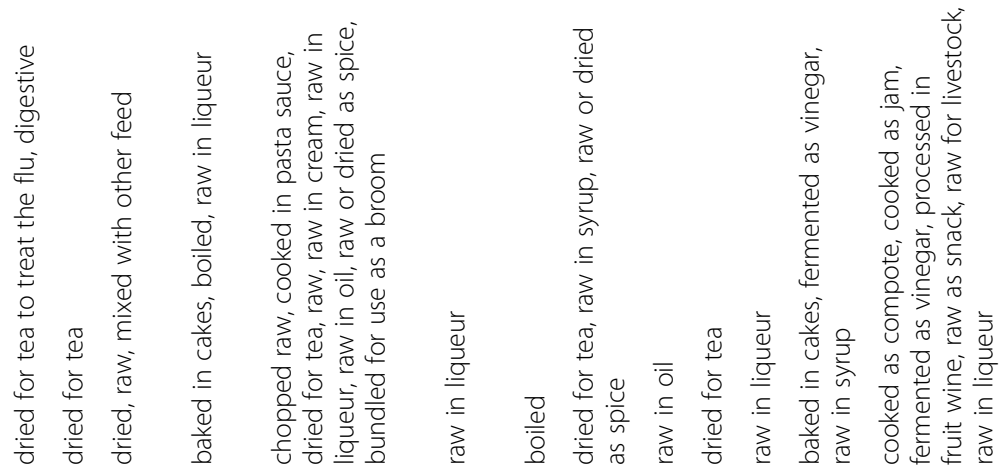


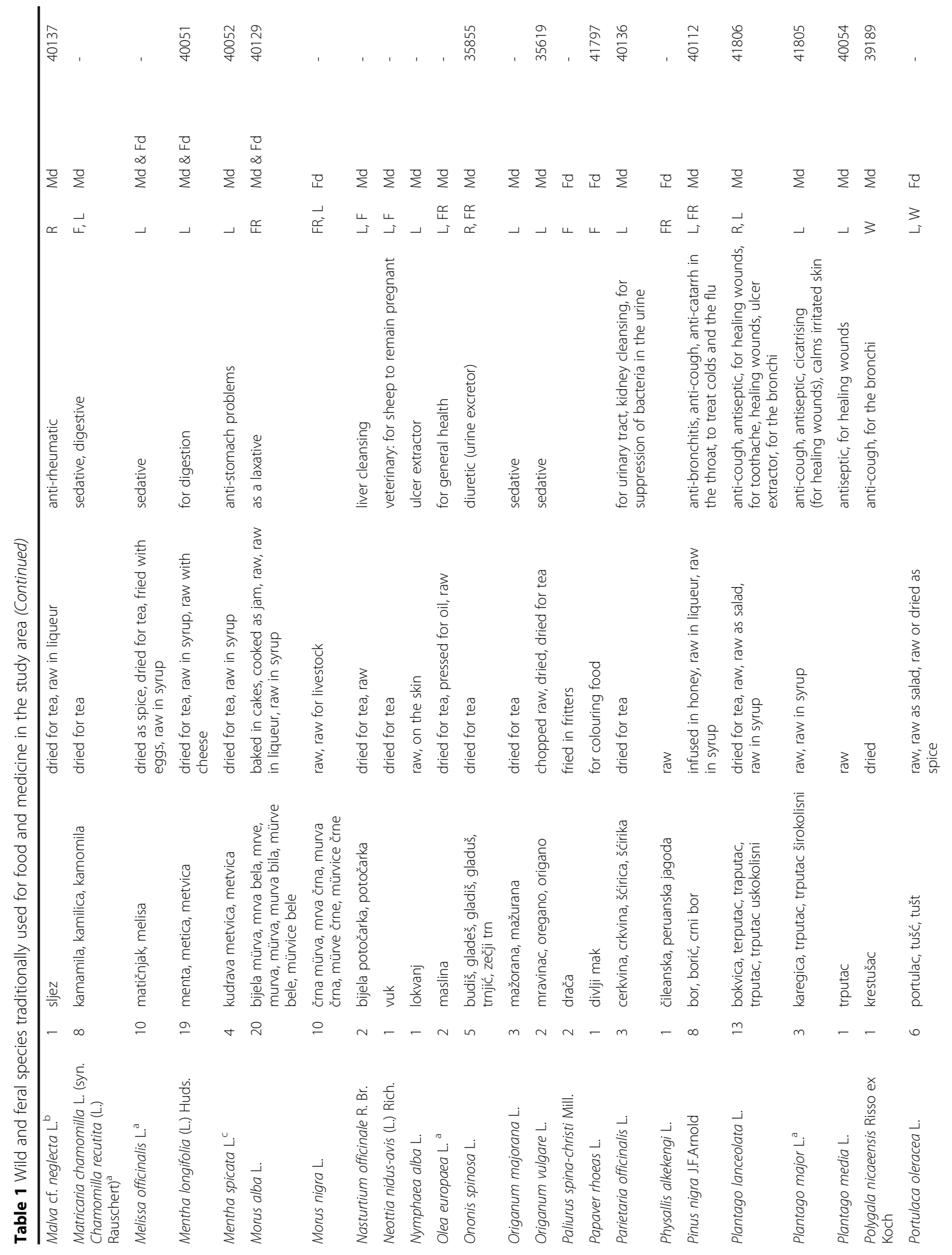




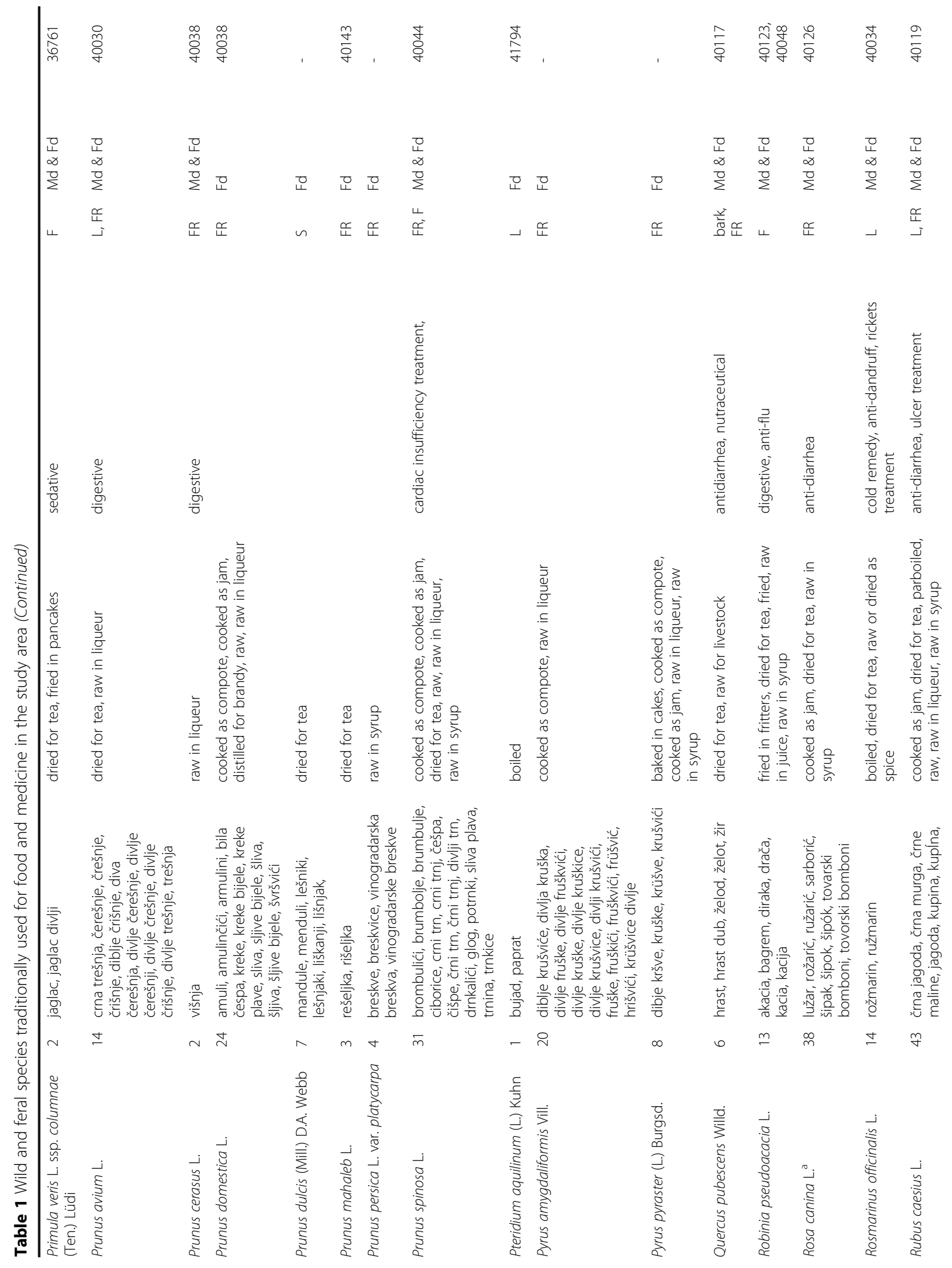




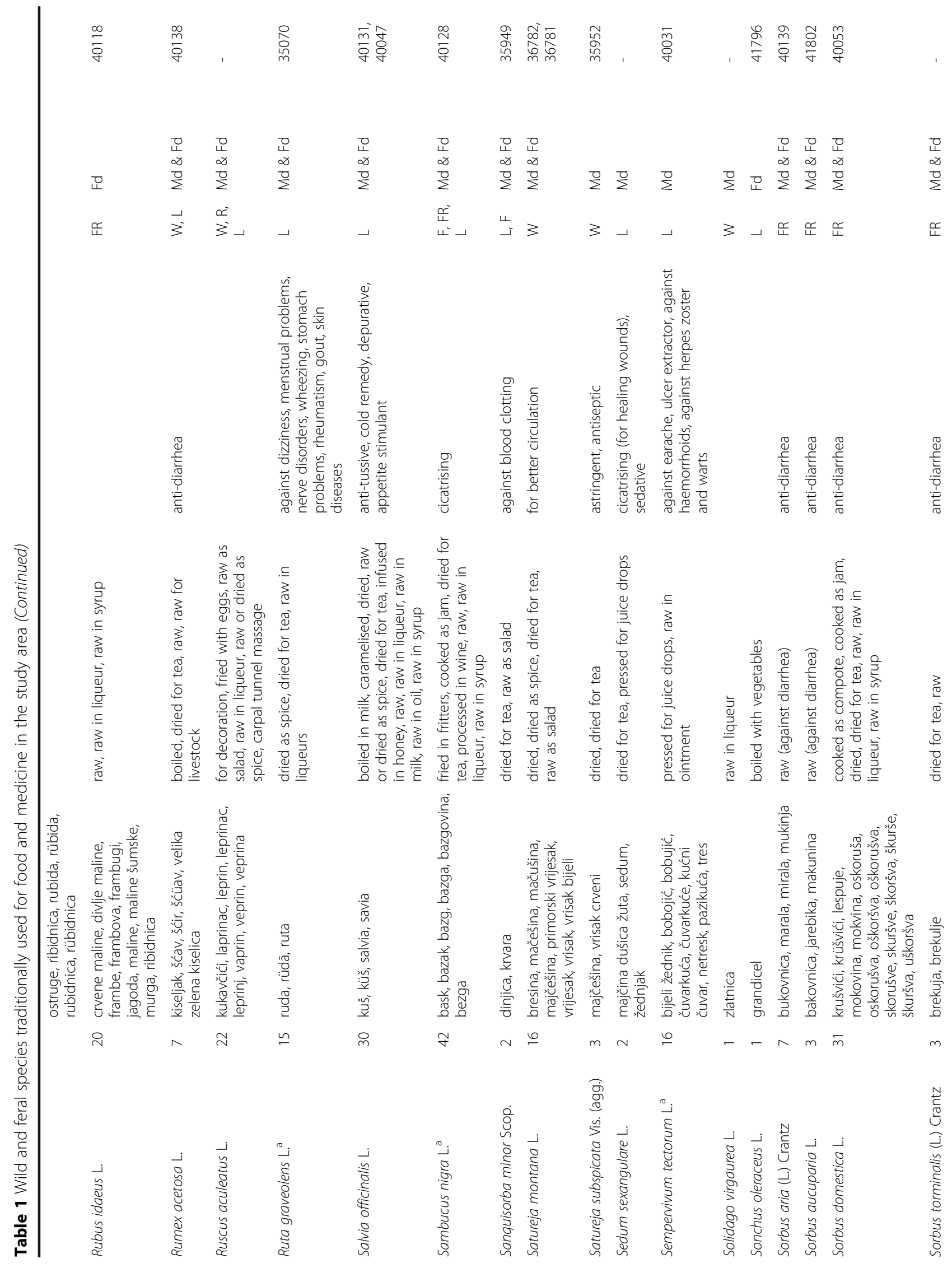




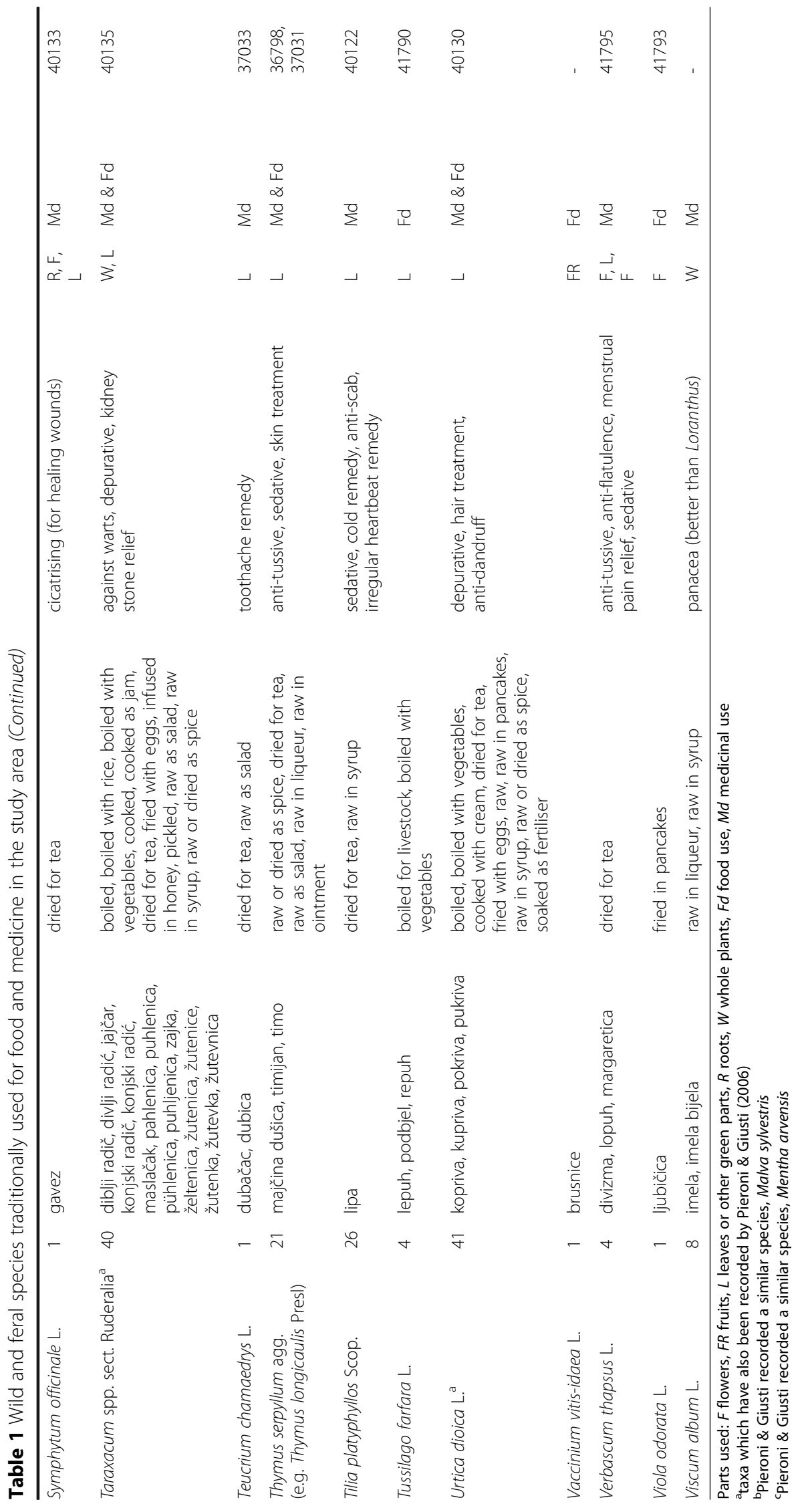


There were also families running small shops or inns [29]. After WWII, due to the slow post-war recovery, poor natural resources for agriculture and high tax burdens imposed on farmers, the structure of the economy and population started to change. In 1961 almost one third of the population in Istria (31.3\%) was living from agriculture, and in 2001 the share was $2.6 \%$ [30].

At present, in most of the settlements there is no livestock and the last charcoal clamp was used at the beginning of 1970-ies. Many highland meadows, that used to be mown once a year and grazed, have become abandoned with the disappearance of livestock. Scarce pieces of fertile land are used mainly for subsistence farming, or as gardens. There is no need for traditional crafts any more, and because of the depopulation, even shops and inns do not exist in small villages. Employed persons mainly commute daily to workplaces in neighbouring towns $[28,29]$. The majority of the population of the research area declared themselves as Croatians (76.5\%), and the second largest group is regionally affiliated (15.2\%). The rest are members of different nationalities (6.9\% altogether) or non-affiliated (1.4\%). However, in this study only Croatian people who were born in the study area and/or spent most of their lives there were interviewed. The interviewed people are mainly retired. All of them have farming backgrounds and were either farmers or worked in Buzet or Kopar and actively maintained gardens.

\section{Methods}

The research was carried out following the Principles of Professional Responsibility of the American Anthropological Association and the International Society of Ethnobiology Code of Ethics (2006) [31, 32]. Data were collected using semi-structured interviews, mainly applying the free listing method, accompanied by informal walks (and talks) with selected key informants, from May to September 2015. To help elicit answers, separate questions were asked about the food use of green parts and fruits as well as medicinal plants that had been personally used by the informants. Additional notes were taken, and audio recordings were made during the interviews when possible. Participants were approached outside, during their farm work, or selected based on recommendation as the most knowledgeable people in the village.

Altogether we obtained data from 50 interviews involving 76 local informants (33 single informant interviews and 17 interviews involving two or three people). There were 37 female and 39 male informants, with a mean age of 67 (age range: 33-101, median: 67).

The interviews were carried out on the territory of three municipalities: Buzet (7 settlements: Buzet, Gornja Nugla, Hum, Kompanj, Počekaji, Roč, Sveti Martin), Lanišće (11 settlements: Brest, Brgudac, Dane, Jelovice,
Klenovšćak, Lanišće, Podgaće, Prapoće, Račja Vas, Slum, Vodice) and Lupoglav (1 settlement: Lupoglav).

Plant names used follow the Plant List [33].

The division between wild and domesticated species is often blurred. Several taxa (mainly fruits and aromatic herbs) listed by the informants occur both in wild and domesticated states. We included them in the species list if we observed significant wild or feral populations of these species in the study area, as in other studies on wild foods in Croatia [34-36].

\section{Results}

Altogether 121 species were recorded as food or medicine, used or previously used in the study area (Table 1). Thirty-one species are used exclusively as food or everyday drink, 50 species are used exclusively as medicine and the use of 40 species overlaps. The mean frequency of species mentioned per questionnaire was 30 (mean no. of exclusively medicinal species 5 , exclusively food species 8 , and 17 from the food-medicine spectrum).

The most commonly used exclusively food species are: Cornus mas L., Cichorium intybus L., Chenopodium album L., Prunus domestica L., Pyrus amygdaliformis Vill., Rubus idaeus L., Clematis vitalba L., Diplotaxis tenuifolia (L.) DC., Fragaria vesca L. and Allium ampeloprasum L. The commonest species used exclusively as medicine are: Achillea millefolium L., Tilia platyphyllos Scop., Hypericum perforatum L., Sempervivum tectorum L., Artemisia absinthium L., Plantago lanceolata L., Gentiana lutea L. ssp. symphyandra (Murb.) Hayek, Althaea officinalis L., Matricaria chamomilla L., and Pinus nigra J.F.Arnold. The most commonly used foodmedicine spectrum species are: Rubus caesius L., Sambucus nigra L., Urtica dioica L., Dioscoraea communis L., Taraxacum spp., Asparagus acutifolius L., Rosa canina L., Foeniculum vulgare Mill., Prunus spinosa L. and Sorbus domestica $\mathrm{L}$.

Wild plants are used for food mainly in the form of preserves (jams, juice), wild vegetables served as salad, manestra soup (served with beans or dried meat) or with omelettes (fritaja), herbal teas or as aromatic additives to alcohol. The mixture of wild vegetables used for the soup is called zelenjava. Its commonest components are Chenopodium, Cichorium, Diplotaxis, Foeniculum and sometimes Humulus or Urtica. Medicinal plants are usually used in the form of infusions and decoctions ("herbal teas"). Such ways of administration were recorded for $52 \%$ of medicinal plant taxa.

Among the most commonly used food and foodmedicinal plants woody species, particularly those of woodland edges are dominant, whereas among medicinal plants it is herbaceous plants from grassland that dominate (Table 2). However, the differences between Ellenberg-Pignatti values (Figs. 3 and 4; Table 3) in the 
Table 2 Ten most commonly used species in each of three categories

\begin{tabular}{|c|c|}
\hline & Habitat in the studied area \\
\hline \multicolumn{2}{|l|}{ Only food plants } \\
\hline Cornus mas L. & forest fringes and clearings \\
\hline Cichorium intybus L. & road verges, ruderal habitats \\
\hline Chenopodium album L. & ruderal habitats, e.g. arable fields \\
\hline Prunus domestica L. & forest fringes (feral) \\
\hline Pyrus amygdaliformis Vill. & forest fringes \\
\hline Rubus idaeus L. & forest firnges \\
\hline Clematis vitalba $\mathrm{L}$. & forest fringes \\
\hline Diplotaxis tenuifolia (L.) DC. & road verges, ruderal habitats \\
\hline Fragaria vesca $\mathrm{L}$. & deciduous forests \\
\hline Allium ampeloprasum L. & road verges, ruderal habitats \\
\hline \multicolumn{2}{|l|}{$\begin{array}{l}\text { Plants from food - medicine } \\
\text { spectrum }\end{array}$} \\
\hline Rubus caesius L. & $\begin{array}{l}\text { forest fringes, hedges, ruderal } \\
\text { habitats }\end{array}$ \\
\hline Sambucus nigra L. & $\begin{array}{l}\text { forest fringes, hedges, ruderal } \\
\text { habitats }\end{array}$ \\
\hline Urtica dioica L. & ruderal habitats \\
\hline Dioscoraea communis L. & forest fringes, hedges \\
\hline Taraxacum spp. & roadsides, lawns, ruderal habitats \\
\hline Asparagus acutifolius L. & $\begin{array}{l}\text { forest fringes, hedges, ruderal } \\
\text { habitats }\end{array}$ \\
\hline Rosa canina L. & forest fringes, hedges \\
\hline Foeniculum vulgare Mill. & road verges, ruderal habitats \\
\hline Prunus spinosa L. & forest fringes, hedges \\
\hline Sorbus domestica L. & forest fringes and clearings \\
\hline \multicolumn{2}{|l|}{ Purely medicinal plants } \\
\hline Achillea millefolium L. & grasslands \\
\hline Tilia platyphyllos Scop. & feral and cultivated in villages \\
\hline Hypericum perforatum L. & grasslands \\
\hline Sempervivum tectorum L. & $\begin{array}{l}\text { feral in rocky places in gardens, } \\
\text { widely cultivated }\end{array}$ \\
\hline Artemisia absinthium L. & $\begin{array}{l}\text { road verges, ruderal habitats, also } \\
\text { cultivated }\end{array}$ \\
\hline Plantago lanceolata $\mathrm{L}$. & road verges, grasslands \\
\hline $\begin{array}{l}\text { Gentiana lutea L. ssp. } \\
\text { symphyandra (Murb.) Hayek }\end{array}$ & dry grasslands \\
\hline Althaea officinalis $\mathrm{L}$. & grasslands \\
\hline Matricaria chamomilla L. & $\begin{array}{l}\text { ruderal habitats, e.g. arable fields, } \\
\text { also cultivated }\end{array}$ \\
\hline Pinus nigra J.F.Arnold. & $\begin{array}{l}\text { forest fringes, used for } \\
\text { afforestation of grasslands }\end{array}$ \\
\hline
\end{tabular}

three categories of useful plants were small and statistically insignificant (Mann-Whitney U test; $P>0.05$ ) apart from the difference between Nitrogen indicator value between the Exclusively Medicinal and the Exclusively
Food category $(P=0.02)$. For Light and Continentality the highest indicator values were observed for medicinal plants and the lowest for food plants (Fig. 6). However median values for these two variables were identified in all three categories (Fig. 7). For Nitrogen the opposite trend was observed - the highest value (and the highest median) was observed for food plants (Figs. 6 and 7). For Temperature and Reaction $(\mathrm{pH})$ the highest indicator values were observed for plants used both for food and medicine (Fig. 6).

\section{Discussion}

The small differences between Ellenberg values for medicinal and food plants can probably be explained by the fact that both these groups incorporate species with very diverse organs used and very diverse phytochemical composition. When designing this study we did however expect that the Light indicator values for medicinal plants would be higher than those of food plants, as many of the medicinal plants grow on dry pastures and roadsides and contain aromatic essential oils. Such a difference actually does occur in our data, but it is not significant. Dry-habitat plants from the Lamiaceae family (13 taxa in our study), rich in essential oils, are some of the basic elements of both local traditional pharmacopeias in the Mediterranean and in Central Europe, and the medicinal plants recommended by written official pharmacopeias. They are particularly useful in healing digestive problems and fighting microbial infection. However, these are usually a few species in a given set of locally used species, and their effect was not significant in a larger matrix of data with species containing different kinds of medicinally active substances. The significant difference in Nitrogen value probably arose due to the fact that several edible plants are nitrophilous weeds, whereas among medicinal plants, as previously mentioned, there are many dry grassland species growing on skeletal soils.

In the use of food the total caloric value is very important and it can be better achieved with higher biomass yields, which are obviously more likely in nitrogen-rich habitats. Most edible green vegetables are plants growing in cultivated crops, on field edges, road margins and other locations in the home yards which have been either intentionally manured, often for centuries, or unintentionally fertilized with human and animal excrements and urine. As a larger biomass of is needed, for food plants compared to medicinal plants, they are more likely to be gathered in a closer vicinity to the house than in these fertilized agro-ecosystems.

The species used in the area are a mix of species typically used in the Mediterranean and in Central Europe, which reflects the character of the vegetation in the study area, intermediate between the two zones. All the 
Table 3 Ellenberg-Pignatti values used in the analysis. For some species and variables the values do not exist

\begin{tabular}{|c|c|c|c|c|c|c|c|c|}
\hline Scientific name & Purpose & Light & Temperature & Continen-tality & Soil moisture & Reaction & Nitrogen & Salinity \\
\hline Allium ampeloprasum L. & food & 7 & 7 & 5 & 3 & 6 & 5 & 0 \\
\hline Allium ursinum L. & food & 2 & & 5 & 6 & 7 & 8 & 0 \\
\hline Amaranthus retroflexus L. & food & 9 & 9 & 7 & 4 & & 9 & 0 \\
\hline $\begin{array}{l}\text { Armoracia rusticana P. Gaertn., } \\
\text { B. Mey. et Scherb. }\end{array}$ & food & 8 & 6 & 5 & 5 & & 9 & 0 \\
\hline Bellis perennis $\mathrm{L}$. & food & 9 & 5 & 4 & & & 5 & 0 \\
\hline Chenopodium album $\mathrm{L}$. & food & 7 & 7 & 5 & 4 & 5 & 7 & 0 \\
\hline Cichorium intybus L. & food & 9 & 6 & 5 & 3 & 8 & 5 & 0 \\
\hline Clematis vitalba $\mathrm{L}$. & food & 7 & 7 & 4 & 5 & 7 & 7 & 0 \\
\hline Cornus mas L. & food & 6 & 7 & 6 & 5 & 8 & 4 & 0 \\
\hline Corylus avellana $\mathrm{L}$. & food & 6 & 5 & 4 & 5 & 5 & 8 & 0 \\
\hline Diplotaxis tenuifolia (L.) DC. & food & 8 & 7 & 5 & 4 & 6 & 5 & 0 \\
\hline Fagus sylvatica L. & food & 3 & 5 & 4 & 5 & & 7 & 0 \\
\hline Fragaria vesca L. & food & 6 & & 4 & 4 & & 5 & 0 \\
\hline Lamium orvala L. & food & 3 & 5 & 5 & 6 & 7 & 8 & 0 \\
\hline Morus nigra L. & food & 8 & 7 & 5 & 5 & 5 & 5 & 0 \\
\hline Paliurus spina-christi Mill. & food & 7 & 8 & 6 & 3 & 7 & 3 & 0 \\
\hline Papaver rhoeas L. & food & 6 & 6 & 5 & 5 & 7 & & 0 \\
\hline Physallis alkekengi $\mathrm{L}$. & food & 6 & 7 & 5 & 7 & 5 & 6 & 0 \\
\hline Portulaca oleracea L. & food & 7 & 8 & 5 & 4 & 7 & 7 & 0 \\
\hline Prunus domestica L. & food & & & & & & & \\
\hline Prunus dulcis (Mill.) D.A. Webb & food & & & & & & & \\
\hline Prunus mahaleb L. & food & 7 & 5 & 6 & 3 & 8 & 2 & 0 \\
\hline Prunus persica L. var. platycarpa & food & & & & & & & \\
\hline Pteridium aquilinum (L.) Kuhn & food & 6 & 5 & 4 & 6 & 3 & 3 & 0 \\
\hline Pyrus amygdaliformis Vill. & food & 7 & 8 & 4 & 4 & 7 & 3 & 0 \\
\hline Pyrus pyraster (L.) Burgsd. & food & 6 & 5 & 5 & 6 & 7 & 7 & 0 \\
\hline Rubus idaeus L. & food & 7 & 4 & & 5 & 5 & 8 & 0 \\
\hline Sonchus oleraceus L. & food & 7 & 5 & & 4 & 8 & 8 & 0 \\
\hline Tussilago farfara $\mathrm{L}$. & food & 8 & & 5 & 6 & 8 & 7 & 0 \\
\hline Vaccinium vitis-idaea $\mathrm{L}$. & food & 5 & 3 & 5 & 4 & 2 & 2 & 0 \\
\hline Viola odorata L. & food & 5 & 6 & 5 & 5 & & 8 & 0 \\
\hline Achillea millefolium L. & med. & 8 & & & 4 & & 5 & 0 \\
\hline Alcea rosea $\mathrm{L}$. & med. & 9 & 8 & 5 & 3 & 6 & 4 & 0 \\
\hline Althaea officinalis $\mathrm{L}$. & med. & 7 & 6 & 6 & 7 & 7 & 6 & 0 \\
\hline Arctium lappa L. & med. & 9 & 5 & 5 & 5 & 7 & 9 & 0 \\
\hline Artemisia absinthium L. & med. & 9 & 6 & 7 & 4 & & 8 & 0 \\
\hline Arum maculatum L. & med. & 3 & 6 & 5 & 7 & 7 & 8 & 0 \\
\hline Calendula officinalis $\mathrm{L}$. & med. & 8 & 7 & 5 & 4 & 5 & 4 & 0 \\
\hline Carlina acaulis L. & med. & 7 & & 4 & 4 & 0 & 2 & 0 \\
\hline Castanea sativa Mill. & med. & 5 & 8 & 6 & & 4 & & 0 \\
\hline Centaurium erythraea Rafn & med. & 8 & 6 & 5 & 5 & 6 & & 0 \\
\hline Chelidonium majus L. & med. & 6 & 6 & & 5 & & 8 & 0 \\
\hline Elymus repens (L.) Gould & med. & 7 & & 7 & 5 & & 8 & 0 \\
\hline
\end{tabular}


Table 3 Ellenberg-Pignatti values used in the analysis. For some species and variables the values do not exist (Continued)

\begin{tabular}{|c|c|c|c|c|c|c|c|c|}
\hline Equisetum arvense $\mathrm{L}$. & med. & 6 & & & 6 & & 3 & 0 \\
\hline Euphorbia cyparissias L. & med. & 7 & 7 & 5 & 3 & 5 & 5 & 0 \\
\hline $\begin{array}{l}\text { Gentiana lutea L. ssp. symphyandra } \\
\text { (Murb.) Hayek }\end{array}$ & med. & 8 & 4 & 5 & 4 & 4 & 2 & 0 \\
\hline Helianthus tuberosus L. & med. & 8 & 7 & 5 & 7 & & 6 & 0 \\
\hline Helichrysum italicum (Roth) G.Don & med. & 8 & 8 & 5 & 4 & 3 & 2 & 0 \\
\hline Hypericum perforatum L. & med. & 7 & 8 & 6 & & & & 0 \\
\hline Ilex aquifolium L. & med. & 4 & 5 & 4 & 5 & 4 & 5 & 0 \\
\hline Iris germanica L. & med. & 7 & 7 & 5 & 3 & 5 & 4 & 0 \\
\hline Iris illyrica Tomm. & med. & & & & & & & \\
\hline Juniperus oxycedrus L. & med. & 8 & 8 & 0 & 3 & 0 & 2 & 0 \\
\hline Lavandula angustifolia Mill. & med. & 11 & 5 & 4 & 3 & 2 & 2 & 0 \\
\hline Linum usitattisimum L. & med. & 9 & 7 & 5 & 4 & 3 & 3 & 0 \\
\hline Loranthus europaeus Jacq. & med. & 7 & 6 & 6 & 5 & & & 0 \\
\hline Malva alcea $\mathrm{L}$. & med. & 8 & 6 & 4 & 5 & 8 & 8 & 0 \\
\hline Matricaria chamomilla L. & med. & 7 & 5 & 5 & 6 & 5 & 5 & 0 \\
\hline Mentha spicata L. & med. & 7 & 6 & 5 & 8 & 8 & 6 & 0 \\
\hline Nasturtium officinale R. Br. & med. & 7 & 4 & 5 & 11 & 7 & 7 & 0 \\
\hline Neottia nidus-avis (L.) Rich. & med. & 2 & 5 & 5 & 5 & 7 & 5 & 0 \\
\hline Nymphaea alba L. & med. & 8 & & 5 & 12 & 7 & 7 & 0 \\
\hline Olea europaea L. & med. & 11 & 10 & 4 & 1 & & 2 & 0 \\
\hline Ononis spinosa L. & med. & 8 & 6 & 5 & & & 3 & 0 \\
\hline Origanum majorana L. & med. & 7 & 7 & 6 & 4 & 5 & 3 & 0 \\
\hline Origanum vulgare L. & med. & 7 & 6 & 5 & 3 & & 3 & 0 \\
\hline Parietaria officinalis $\mathrm{L}$. & med. & 4 & 8 & 4 & 5 & 7 & 7 & 0 \\
\hline Pinus nigra J.F.Arnold & med. & 7 & 7 & 4 & 2 & 9 & 2 & 0 \\
\hline Plantago lanceolata L. & med. & 6 & 7 & 5 & & & & 0 \\
\hline Plantago major $\mathrm{L}$. & med. & 8 & & & 5 & & 7 & 0 \\
\hline Plantago media L. & med. & 7 & & 7 & 4 & 8 & 3 & 0 \\
\hline Polygala nicaeensis Risso ex Koch & med. & 8 & 6 & 5 & 3 & 7 & 2 & 0 \\
\hline Satureja subspicata Vis. & med. & 8 & 5 & 7 & 4 & 7 & 3 & 0 \\
\hline Sedum sexangulare L. & med. & 7 & 5 & 4 & 7 & 8 & 1 & 0 \\
\hline Sempervivum tectorum $\mathrm{L}$. & med. & 8 & 5 & 5 & 2 & 4 & & 0 \\
\hline Solidago virgaurea L. & med. & 5 & & & 5 & & 5 & 0 \\
\hline Symphytum officinale L. & med. & 7 & 6 & 4 & 8 & & 8 & 0 \\
\hline Teucrium chamaedrys L. & med. & 7 & 6 & 5 & 2 & 8 & 1 & 0 \\
\hline Tilia platyphyllos Scop. & med. & 3 & 5 & 4 & 5 & & 7 & 0 \\
\hline Verbascum thapsus L. & med. & 8 & & 4 & 4 & 7 & 7 & 0 \\
\hline Viscum album L. & med. & 7 & 5 & 5 & 0 & 0 & 0 & 0 \\
\hline Amaranthus retroflexus $\mathrm{L}$. & med. \& food & 9 & 9 & 7 & 4 & & 9 & 0 \\
\hline Asparagus acutifolius L. & med. \& food & 6 & 9 & 4 & 2 & 5 & 5 & 0 \\
\hline Carum carvi L. & med. \& food & 8 & 4 & 5 & 5 & & 6 & 0 \\
\hline $\begin{array}{l}\text { Clinopodium nepeta (L.) Kuntze } \\
\text { (syn. Calamintha nepetoides Jord.) }\end{array}$ & med. \& food & 5 & 7 & 5 & 3 & 9 & 3 & 0 \\
\hline Crataegus monogyna Jacq. & med. \& food & 6 & 7 & 5 & 4 & 6 & 3 & 0 \\
\hline Daucus carota $\mathrm{L}$. & med. \& food & 8 & 6 & 5 & 4 & 5 & 4 & 0 \\
\hline
\end{tabular}


Table 3 Ellenberg-Pignatti values used in the analysis. For some species and variables the values do not exist (Continued)

\begin{tabular}{|c|c|c|c|c|c|c|c|c|}
\hline $\begin{array}{l}\text { Dioscoraea communis (L.) } \\
\text { Caddick \& Wilkin } \\
\text { (syn. Tamus communis L.) }\end{array}$ & med. \& food & 5 & 7 & 5 & 5 & 8 & 6 & 0 \\
\hline Foeniculum vulgare Mill. & med. \& food & 9 & 8 & 5 & 3 & 7 & 7 & 0 \\
\hline Humulus lupulus L. & med. \& food & 7 & 6 & 4 & 8 & 6 & 8 & 0 \\
\hline Juglans regia L. & med. \& food & 6 & 6 & 6 & 5 & 6 & 6 & 0 \\
\hline Juniperus communis L. & med. \& food & 8 & 0 & 0 & 4 & 0 & 4 & 0 \\
\hline Laurus nobilis L. & med. \& food & 2 & 7 & 4 & 8 & 4 & 6 & 0 \\
\hline Malus domestica Borkh. & med. \& food & 7 & 7 & 5 & 5 & 5 & 5 & 0 \\
\hline Malus sylvestris Mill. & med. \& food & 8 & 6 & 4 & 4 & & 8 & 0 \\
\hline Melissa officinalis L. & med. \& food & 6 & 7 & 5 & 4 & 6 & 4 & 0 \\
\hline Mentha longifolia (L.) Huds. & med. \& food & 7 & 5 & 5 & 8 & 8 & 8 & 0 \\
\hline Morus alba L. & med. \& food & 8 & 7 & 5 & 5 & 5 & 5 & 0 \\
\hline $\begin{array}{l}\text { Primula veris L. ssp. columnae } \\
\text { (Ten.) Lüdi }\end{array}$ & med. \& food & 7 & & 3 & 4 & 8 & 3 & 0 \\
\hline Prunus avium L. & med. \& food & 4 & 5 & 6 & 5 & 7 & 5 & 0 \\
\hline Prunus cerasus L. & med. \& food & 9 & 7 & 6 & 5 & 5 & 5 & 0 \\
\hline Prunus spinosa L. & med. \& food & 7 & 5 & 5 & & & & 0 \\
\hline Quercus pubescens Willd. & med. \& food & 7 & 8 & 6 & 3 & 7 & 4 & 0 \\
\hline Robinia pseudoacacia L. & med. \& food & 5 & 7 & 5 & 4 & & 8 & 0 \\
\hline Rosa canina L. & med. \& food & 8 & 5 & 5 & 4 & & & 0 \\
\hline Rosmarinus officinalis $\mathrm{L}$. & med. \& food & 11 & 8 & 4 & 2 & 6 & 1 & 0 \\
\hline Rubus caesius L. & med. \& food & 7 & 5 & 5 & 7 & 7 & 9 & 0 \\
\hline Rumex acetosa L. & med. \& food & 4 & 8 & 5 & 4 & 5 & 5 & 0 \\
\hline Ruscus aculeatus L. & med. \& food & 8 & & & & 4 & 5 & 0 \\
\hline Ruta graveolens $\mathrm{L}$. & med. \& food & 9 & 7 & 6 & 3 & 7 & 2 & 0 \\
\hline Salvia officinalis $L$. & med. \& food & 11 & 6 & 6 & 2 & 7 & 1 & 0 \\
\hline Sambucus nigra L. & med. \& food & 7 & 5 & 4 & 5 & & 9 & 0 \\
\hline Sanquisorba minor Scop. & med. \& food & 7 & 6 & 5 & 3 & 8 & 2 & 0 \\
\hline Satureja montana L. & med. \& food & 8 & 6 & 6 & 3 & 7 & 2 & 0 \\
\hline Sorbus aria (L.) Crantz & med. \& food & 6 & 5 & 5 & 4 & 7 & 3 & 0 \\
\hline Sorbus aucuparia L. & med. \& food & 6 & & & & & & 0 \\
\hline Sorbus domestica L. & med. \& food & 4 & 7 & 5 & 3 & 8 & 3 & 0 \\
\hline Sorbus torminalis (L.) Crantz & med. \& food & 4 & 6 & 5 & 4 & 7 & 4 & 0 \\
\hline Taraxacum spp. sect. Ruderalia & med. \& food & 7 & & & 5 & & 7 & 0 \\
\hline $\begin{array}{l}\text { Thymus serpyllum agg. } \\
\text { (e.g. Thymus longicaulis Presl) }\end{array}$ & med. \& food & 7 & 7 & 7 & 4 & 7 & 3 & 0 \\
\hline Urtica dioica L. & med. \& food & & & & 6 & & 8 & 0 \\
\hline
\end{tabular}

species used were reported in other ethnobotanical works from Croatia or neighbouring countries, e.g. [34-44]. A particular feature of the local cuisine is scrambled eggs (fritaja) prepared with young shoots of Ruscus aculeatus and Cannabis sativa seeds and oil, used against diabetes and high pressure, and to boost immunity. It is interesting that Humulus lupulus is still used as a vegetable, unlike on the north Adriatic island of Krk, where people used to use it, but it is now completely forgotten [36]. Previous studies also paid attention to a relatively "unoriginal" list of plant remedies used in Ćićarija [13, 17]. However, this may be explained by the fact that phytotherapy was quite developed in this part of Europe, hence most medicinal plants in the area had already been described in detail in Renaissance herbals. A similar high correspondence between the written pharmacopeias and the present choice of plants used can be 


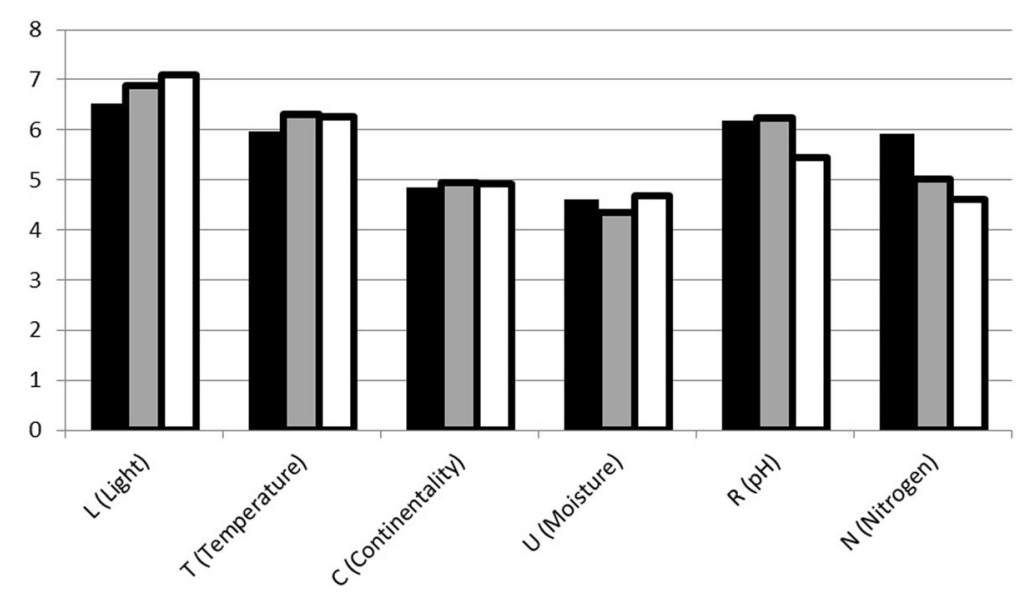

Fig. 6 Mean Ellenberg values for exclusively food species (black bars), food and medicinal species (grey bars) and exclusively medicinal species (white bars)

found in other European countries as well [45-47]. Compared to the previous study of Croatian plant folk remedies in Cićarija [13] we found more plant remedies used (even when the list was restricted to the same villages studied by Pieroni \& Giusti). Pieroni and Giusti mentioned 25 plants. We confirmed the use of all the wild and semi-wild species mentioned by them (19 taxa), except for two taxa where we found the use of a different species but within the genus mentioned in their work (Malva and Mentha). In our study we found 54 species of plants mentioned by our respondents in the villages studied by those authors (Jelovice, Dane, Vodice, Trstenik, Račja Vas, Lanišce, Prapoće, Brgudac). It is difficult to compare these studies as in this previous work the number of respondents and frequency of citation was not mentioned.
We can however hypothesize that the larger number of species recorded in our study stems mainly from two factors. First of all the previous researchers were outsiders speaking Italian to local residents, who may not have been able to express everything in Italian. The first author of our study has spent twelve years researching Ćićarija and thus knows many people well, which may have given respondents more confidence. Secondly, in recent years more and more literature on herbal remedies has become available to the general public, which may result in some new uses, the re-invention of old uses or help in the remembrance of old uses $[45,46]$. This may have happened even in spite of our intention not to record "literature" uses little ingrained in the habits of local people, or very recently acquired.

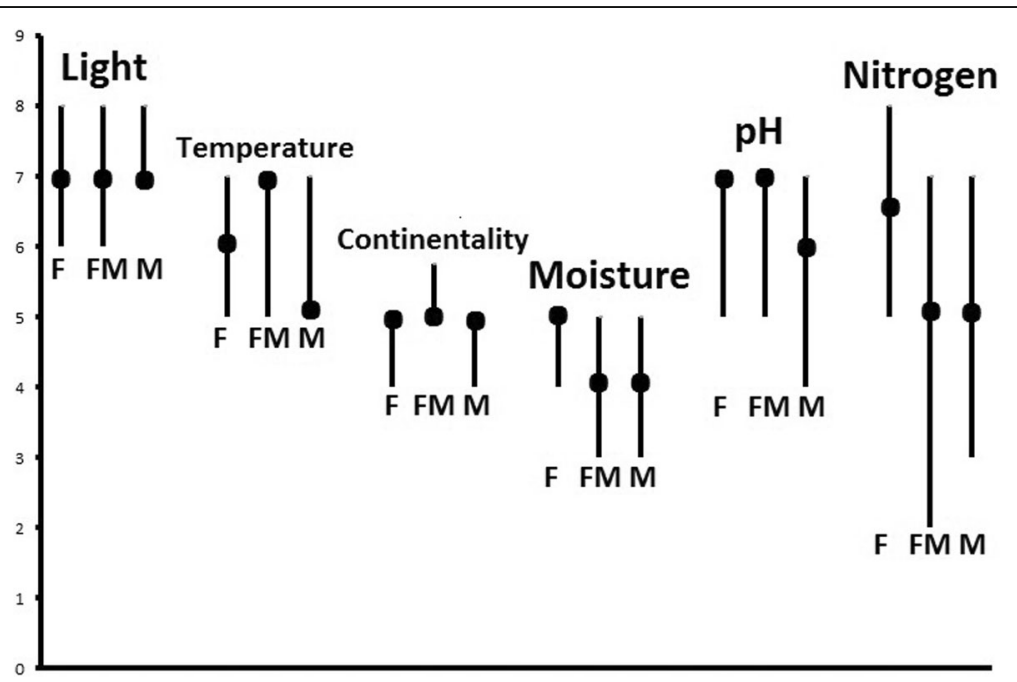

Fig. 7 Medians (black circles) and first and third quartiles for Ellenberg values (values indicated by line tips). F - exclusively food species, FM food and medicinal species, M - exclusively medicinal species 


\section{Conclusions}

The differences between Ellenberg values of medicinal and food plants collected in the study area are negligible. The only significant differences were detected for the Nitrogen value. This is probably caused by the fact that edible green vegetables are mainly species of nitrogenrich agro-ecosystems. It could be interesting to carry out a similar study in some other regions of Europe where Ellenberg values are accessible in order to see if the results we achieved show a typical pattern in the relation between food and medicinal plants.

\section{Acknowledgments}

Our special thanks go to the study participants from Mount Ćićarija who generously shared their knowledge, especially to the Zlatić and Tolušić families who gave us lodging.

\section{Funding}

The field research was financed privately with a small finance donation from the Town of Buzet. The publication of the paper was financed by the Institute of Applied Biotechnology and Basic Sciences, University of Rzeszów.

\section{Availability of data and materials}

Voucher specimens were collected with informants, deposited and digitized in the herbarium of the Faculty of Agriculture of Zagreb University - ZAGR Virtual herbarium (http://herbarium.agr.hr/)

The original matrix for calculating Ellenberg values is included as Table 2.

The original data sheet with interviews is available upon reasonable request.

\section{Authors' contributions}

Field work: IVK (all interviews) and $Ł$ (three interviews), data analysis and writing the text - all the authors. All authors read and approved the final manuscript.

\section{Competing interests}

The authors declare that they have no competing interests.

\section{Consent for publication}

Not applicable.

\section{Ethics approval and consent to participate}

The research adhered to the local traditions for such research and the Code of Ethics of the International Society of Ethnobiology (ISE 2008). Prior oral informed consent was obtained from all study participants. No ethical committee permits were required. No permits were required to collect voucher specimens.

\section{Publisher's Note}

Springer Nature remains neutral with regard to jurisdictional claims in published maps and institutional affiliations.

\section{Author details}

${ }^{1}$ Department of Agricultural Botany, University of Zagreb Faculty of Agriculture, Svetošimunska 25, 10000 Zagreb, Croatia. ${ }^{2}$ Department of Management and Rural Entrepreneurship, University of Zagreb Faculty of Agriculture, Svetošimunska 25, 10000 Zagreb, Croatia. ${ }^{3}$ Department of Botany, Institute of Biotechnology, University of Rzeszów, Werynia 502, 36-100 Kolbuszowa, Poland.

Received: 7 March 2017 Accepted: 17 May 2017

Published online: 02 June 2017

\section{References}

1. Ellenberg H. Zeigerwerte der Gefässpflanzen Mitteleuropas. Scripta Geobotanica. 1974;9:1-97.

2. Ellenberg $H$, Weber HE, Düll $R$, Wirth $V$, Werner W, Paulißen D. Zeigerwerte von Pflanzen in Mitteleuropa. Scripta Geobotanica. 1992;18(2):1-258.
3. Landolt E. Ökologische Zeigerwerts zur Schweizer Flora. Veröff. Geobot. Inst. ETH. Zurich. 1977;64:1-208.

4. Hill MO. Ellenberg's indicator values for British plants. Huntingdon: Institute of Terrestrial Ecology; 1999.

5. Zarzycki K. Indicator values of vascular plants in Poland. Krakow: Instytut Botaniki Polska Akademia Nauk; 1984

6. Pignatti S, Menegoni P, Pietrosanti S. Biondicazione attraverso le piante vascolari. Valori di indicazione secondo Ellenberg (Zeigerwerte) per le specie della Flora d'Italia. Braun-Blanquetia. 2005;39:1-97.

7. Hawkes JC, Pyatt DG, White IMS. Using Ellenberg indicator values to assess soil quality in British forests from ground vegetation: a pilot study. J Appl Ecol. 1997;34:375-87.

8. Dzwonko Z. Assessment of light and soil conditions in ancient and recent woodlands by Ellenberg indicator values. J Appl Ecol. 2001;38:942-51.

9. Schaffers AP, Sýkora KV. Reliability of Ellenberg indicator values for moisture, nitrogen and soil reaction: a comparison with field measurements. J Veg Sci. 2000;11:225-44

10. Zeleny D, Schaffers AP. Too good to be true: pitfalls of using mean Ellenberg indicator values in vegetation analyses. J Veg Sci. 2012;23:419-31.

11. De Albuquerque UP. Quantitative ethnobotany or quantification in ethnobotany. Ethnobot Res Appl. 2009:7:1-4.

12. Albuquerque UP, Ramos MA, de Lucena RF, Alencar NL. Methods and techniques used to collect ethnobiological data. New York: Springer; 2014.

13. Pieroni A, Giusti ME. The remedies of the folk medicine of the Croatians living in Ćićarija, northern Istria. Coll Antropol. 2008;32(2):623-7.

14. Voeks RA. Disturbance pharmacopoeias: medicine and myth from the humid tropics. Ann Assoc Amer Geogr. 2004;94(4):868-88.

15. Stepp JR, Moerman DE. The importance of weeds in ethnopharmacology. Jthnopharmacol. 2001;75(1):19-23.

16. Castaneda $\mathrm{H}$, Stepp JR. Ethnoecological importance value (EIV) methodology: assessing the cultural importance of ecosystems as sources of useful plants for the Guaymi people of Costa Rica. Ethnobot Res Appl. 2007;5:249-57.

17. Pieroni A, Giusti ME, Münz H, Lenzarini C, Turković G, Turković A. Ethnobotanical knowledge of the Istro-Romanians of Žejane in Croatia. Fitoterapia. 2003;74(7):710-9.

18. Vitasović Kosić I, Tardella FM, Ruščić M, Catorci A. Assessment of floristic diversity, functional composition and management strategy of North Adriatic pastoral landscape (Croatia). Pol J Ecol. 2011;59(4):765-76.

19. Vitasović Kosić I, Tardella FM, Grbeša D, Škvorc Ž, Catorci A. Effects of abandonment on the functional composition and forage nutritive value of a North Adriatic dry grassland community (Ćićarija, Croatia). Appl Ecol Env Res. 2014;12(1):285-99.

20. Vitasović Kosić I, Tardella FM, Catorci A. Effect of management modification on the coenological composition of the North Adriatic pastoral landscape (Ćićarija, Croatia). Hacquetia. 2012;11(1):17-46.

21. Vitasović Kosić I.. Grasslands Scorzonero-Chrysopogonetalia order on the Ćićarija: Flora, Vegetation and Feed value. Zagreb: Doctoral Dissertation, University of Zagreb, Faculty of Agriculture; 2011.

22. Snoj M. Etimološki slovar slovenskih zemljepisnih imen. Ljubljana: Modrijan and Založba ZRC; 2009.

23. Poldini L. La vegetazione del Carso isontino e triestino. Studio del paesaggio vegetale tra Trieste, Gorizia e i territori adiacenti. Trieste: Edizioni; 1989.

24. Kaligarič M. Rastlinstvo primorskega krasa in Slovenske Istre - Travniki in pašniki. Zgodovinsko društvo za južno primorsko. Koper: Znanstveno raziskovalno središče Republike Slovenije Koper; 1997.

25. Bertoša M, Matijašić $R$, editors. Istarska enciklopedija. Zagreb: Leksikografski zavod Miroslav Krleža; 2005.

26. Zadnik D, Sotlar M, Volčič T, Mrzlić D, Šubara G, editors. Zgodovinski pomen paše in pašništva za okolje.KGZS- Kmetijsko gozdarski zavod Nova Gorica. Nova Gorica, Grafika Soča d.o.o; 2013.

27. Central Bureau of Statistics of the Republic of Croatia. Census of Population, Households and Dwellings. 2011. http://www.dzs.hr/Eng/censuses/ census2011/results/htm/e01_01_47/E01_01_47.html Accessed 8 Feb 2017

28. Par $V$, Njavro M, Hadelan L, Šakić B. Strateški program ruralnog razvoja Istarske županije (2008-2013). County of Istria. http://www.istra-istria.hr/ uploads/media/Ruralni_razvoj_2008-2013studija.pdf Accessed 10 Feb 2017.

29. Škiljan F. Iz svakodnevnoga života sela Žejane u dvadesetom stoljeću (From everyday life in Žejane village in the 20th century). Histria: godišnjak Istarskog povijesnog društva. 2014; 4(4):141-170. 
30. Zupanc I. Demogeografski razvoj Istre od 1945. do 2001. (Population Development of Istria in the Period 1945-2001). Hrvatski geografski glasnik. 2004;66(1):67-102.

31. Principles of Professional Responsibility. American Anthropological Association. http://ethics.americananthro.org/category/statement/ Accessed 24 May 2017.

32. International Society of Ethnobiology Code of Ethics (with 2008 additions). http://ethnobiology.net/code-of-ethics/. Accessed 10 Feb 2017.

33. The Plant List: a working list of all plant species. http://www.theplantlist. org/. Accessed 10 Feb 2017.

34. Dolina K, Łuczaj Ł. Wild food plants used on the Dubrovnik coast (southeastern Croatia). Acta Soc Bot Pol. 2014;83(3):175-81.

35. Łuczaj Ł, Fressel N, Perković S. Wild food plants used in the villages of the Lake Vrana Nature Park (northern Dalmatia, Croatia). Acta Soc Bot Pol. 2013:82(4):275-81.

36. Dolina K, Jug-Dujaković M, Łuczaj Ł, Vitasović-Kosić I. A century of changes in wild food plant use in coastal Croatia: the example of Krk and Poljica history. Acta Soc Bot Pol. 2016;85(3):3508.

37. Paoletti MG, Dreon AL, Lorenzoni GG. Pistic, traditional food from western Friuli, N.E. Italy. Econ Bot. 1995;49(1):26-30.

38. Guarrera PM. Usi e tradizioni della flora italiana. Aracne: Rome; 2004.

39. Ghirardini MP, Carli M, del Vecchio N, Rovati A, Cova O, Valigi F, et al. The importance of a taste. A comparative study on wild food plants consumption in twenty-one local communities in Italy. J Ethnobiol Ethnomed. 2007;3:22

40. Hadjichambis AC, Paraskeva-Hadjichambi D, Della A, Giusti ME, De Pasquale C, Lenzarini C, et al. Wild and semi-domesticated food plant consumption in seven circum-Mediterranean areas. Int J Food Sci Nutr. 2008;59(5):383-414.

41. Łuczaj Ł, Dolina K. A hundred years of change in wild vegetable use in southern Herzegovina. J Ethnopharmacol. 2015;166:297-304.

42. Dénes A, Papp N, Babai D, Czúcz B, Molnár Z. Wild plants used for food by Hungarian ethnic groups living in the Carpathian Basin. Acta Soc Bot Pol. 2012:81(4):381-96.

43. Grasser S, Schunko C, Vogl CR. Gathering "tea"-from necessity to connectedness with nature. Local knowledge about wild plant gathering in the biosphere reserve grosses Walsertal (Austria). J Ethnobiol Ethnomed. 2012;8(1):31.

44. Lumpert M, Kreft S. Folk use of medicinal plants in Karst and Gorjanci, Slovenia. J Ethnobiol Ethnomed. 2017:13(1):16.

45. Köhler P. The romantic myth about the antiquity of folk botanical knowledge and its fall: Józef Rostafiński's case. Acta Baltica Historiae et Philosophiae scientiarum. 2015;3(1):99-108.

46. Leonti $\mathrm{M}$. The future is written: Impact of scripts on the cognition, selection, knowledge and transmission of medicinal plant use and its implications for ethnobotany and ethnopharmacology. J Ethnopharmacol. 2011;134(3):542-55.

47. Dal Cero M, Saller R, Weckerle CS. The use of the local flora in Switzerland: a comparison of past and recent medicinal plant knowledge. J Ethnopharmacol. 2014;151(1):253-64

\section{Submit your next manuscript to BioMed Central and we will help you at every step:}

- We accept pre-submission inquiries

- Our selector tool helps you to find the most relevant journal

- We provide round the clock customer support

- Convenient online submission

- Thorough peer review

- Inclusion in PubMed and all major indexing services

- Maximum visibility for your research

Submit your manuscript at www.biomedcentral.com/submit
C Biomed Central 